\title{
Interview with Brian Tomlinson on Humanising Education
}

\author{
Interviewed by \\ Vahid Nimehchisalem \\ Faculty of Modern Languages and Communication, Universiti Putra Malaysia, Malaysia \\ E-mail: vahid@upm.edu.my
}

Received: -

doi:10.7575/aiac.ijels.v.4n.2p.101
Accepted: -

Published: $30-04-2016$

URL: http://dx.doi.org/10.7575/aiac.ijels.v.4n.2p.101

\section{Introduction}

Brian Tomlinson is a Visiting Professor at The University of Liverpool and a TESOL Professor at Anaheim University. He has worked as a teacher, teacher trainer, curriculum developer, university academic and soccer coach in Indonesia, Japan, Nigeria, Oman, Singapore, Vanuatu, UK and Zambia and has given presentations in over 60 countries. He is the Founder and President of MATSDA and has published many articles and books including Developing Materials for Language Teaching, Openings etc.

The interview you are about to read here was recorded after his plenary talk at the $11^{\text {th }}$ Malaysia International Conference on English Language Teaching (MICELT 2016) in Swiss-Garden Beach Resort, Damai Laut, Perak, Malaysia.

\section{The interview}

$\mathbf{V N}^{1}$ : What does Humanising Education mean to Brian Tomlinson?

BT $^{2}$ : Basically making the education relevant to the individual learner so that the learner isn't treated just as a student in a large class but as an individual human being, with intelligence, emotions, feelings, higher experience, interests, and attributes. I believe we should strive to connect with the individual. And, a lot of education doesn't do this.

VN: Did you use the words 'learner' and 'student' purposefully?

BT: Yes, I did. I'm using 'learner' as positive and 'student' in some way as a negative because it attributes a role to the learner and it limits, and 'student' also implies studying and there is a lot more to education than just studying.

VN: So, a student is the learner in a cage compelled to go through a top-down type of developed curriculum and materials perhaps.

BT: In my plenary, I quoted William Blake;

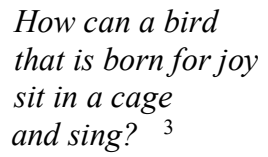

How can a bird

that is born for joy

sit in a cage

and sing? 3

The learner is born for joy but he can become a student restricted to a cage of misery.

VN: How can education be humanised? Can it be humanised? Because we are talking about education. And when talking about education, we remember cages, schools and books especially in Asia. Is it possible to humanise education?

BT: It's pretty easy. If we are talking particularly about developing materials for the classroom, then I would start with universal principles. What do we know about what facilitates language acquisition, basic things like exposure to language use, opportunities to use the language for communication, and also how learners discover things for themselves. So, I would take the discovery approach and I think this is the human approach in which each individual can select a different route to learn. It doesn't matter whether they can discover what's in the curriculum; what matters is that they develop a curiosity about the language and any other subject they are learning and explore it for themselves and get from it what they can as an individual; sometimes also working with other learners in teams so that you've got collaborative learning as well. But, the main thing is that the individual that is catered. And, anyway you can do that by offering a choice, ideally a choice of text, it's easy for the learner to find their own text. So, you can have a set of generalizable activities; the learner chooses which of those activities to do, and chooses which reading or listening or viewing text to do the activities with. I'm trying to persuade publishers to do that, but so far they are reluctant.

\footnotetext{
${ }^{1}$ Vahid Nimehchisalem

${ }^{2}$ Brian Tomlinson

${ }^{3}$ The poem available at http://www.online-literature.com/blake/630/
} 
It's easy to have a web course, say, you've got a particular genre, which might be newspapers, and you've got a set of generalizable activities, and the learner would simply go to the web, select a newspaper, select a page which they are interested in and use it to drive the activities. So it's not that difficult to do.

VN: I think it's more difficult to come up with a dehumanised type of education?

BT: In fact, it is. To dehumanise education people need three years of training. To humanise it, they need to be encouraged to be themselves. And to think of themselves not as a teacher, but as a human being helping other human beings to learn.

VN: So, humanising textbooks, education or assessment is not a complicated process. All you need to do is to undo what we have been doing.

BT: Yes, That's it. Exactly. I haven't always given it the label 'humanising' but I think ever since my first horrendous year as a teacher when I made all the mistakes. Even in my first year as a teacher, I remember attempting to humanise but not being very successful because I was very new and very young. Yes, I remember taking a class for their English lesson in the gym and we dramatised the texts from the book, the coursebook, in the gym, but unfortunately this was a very rowdy class, and they ran wild in the gym and did a lot of damage and I got into big trouble. The main reason why we have dehumanised education is so we can exert control, control of behaviour and control of attitudes. It's all part of this, I suppose, inevitable process, where the main concern of the establishment is to preserve the status quo and to preserve the way people think because that's how they stay in control, stay in power, so in a way it's political. And if you humanise, then it's subversive, it's radical, it risks creating a lot of free spirits; you will be challenged. So, the teacher's responsibility in my view is to humanise education but at the same time, maintain enough control to provide security and avoid being too subversive. I don't find a problem with behaviour; I find you get bad behaviour if students are bored. If you challenge them and give them the opportunity to be creative and to follow their own interests, and their own choices, then I'm telling you there aren't many problems with student behaviour. I've observed hundreds of classes all over the world and I've looked for the kids who were misbehaving and they were always amongst the brightest kids but then they are not being challenged and respected and they are being bored and therefore they misbehave. The best way to control is to engage, and when everyone is engaged, then no one is misbehaving.

VN: So, are we saying that people choose dehumanised education to help them, perhaps better manage the classroom?

BT: Certainly. It's a big factor.

VN: ... because when you decide to be a humanistic teacher, you're risking.

BT: Yes, you are taking a risk; it's unpredictable. You cannot predict what's going to happen. You've got an idea from your previous experience, but it could go anyway and if you are humanistic, you've got to let it go off in many different directions. So, you are taking a risk because you are not following the curriculum, for example, in the expected way. You could still follow the curriculum and be humanistic; it's quite possible, but you are doing it in a different way.

VN: In your plenary, you gave us a very good example. It was a textbook dialogue, you asked us to read it. You just made a very small change to the instructions and told us to imagine the two people buying and selling shoes have recently been divorced and then to try acting it with the right intonation. And then, you made it even more interesting by asking us to think of some inner voice utterances, to guess what was going on in the characters' minds.

BT: Yes, it's a reflection of reality and shows how human beings behave.

VN: So, humanising Education doesn't mean, literally taking the student out of the classroom, to the gym, or changing the textbook. It may be a simple change in the textbook instructions.

BT: And, it takes only five minutes to think of that. And once you get used to doing it, you can do it with any page and any coursebook, five minutes' thinking; that'll do.

VN: And perhaps the minute you do it, your students also give you ideas.

BT: Yes, Definitely.

VN: ...because their creativity has been unleashed, and they know that they can try something new.

BT: And sometimes, they'll do something which you didn't actually expect and didn't tell them to do and if it becomes interesting, you just let it go.

VN: And, that becomes a good idea for the next classes.

BT: So all the time, you are getting new ideas, and each time you do it, you do it differently.

VN: It becomes a virtuous cycle of creativity.

BT: Yes. That's right. Often teachers are frightened about it but they can do it, they can all do it. When I do teachers' courses and workshops, they all say, "It's alright for you; you have got experience; you have an out-going personality; I can't do that." "Oh yes, you can", I say and two days later, they are doing it; no problem. 
VN: Is humanising education culture-bound? People may be asking, "Will this work in Africa, Asia, Indonesia, or Malaysia or Iran?" What would you tell them?

BT: Yes, It will work anywhere, but you do have to explain what you are doing. If what you are doing is radically different from what the students expect, then when you start to do it, you talk to them about it. You tell them why you are going to do it. And you involve them in it. And then you have to, you know, I always say, after three goes, have a reflective phase, and ask, "What do you think?", "Are you enjoying this?" "Is this worth doing?" "Shall we continue?" And, always we've continued. So, I've done this in Africa, in Nigeria and Zambia, and Namibia and some other countries actually, Ethiopia, Senegal, and I've done this in Asia, in Indonesia, Oman, Malaysia, Japan, and in the South Pacific, in Vanuatu.

VN: Was there any resistance on the part of the students?

BT: No, Not from the students. The only resistance I got sometimes was from the teachers. It wasn't resistance; for example, in Japan, I was teaching at Kobe University and students could choose which class to go to, and I got 90 in my class. So I had the biggest classes because they saw that my class was enjoyable; we had fun. And the other teachers said, "What's the secret?" So, I gave a workshop for the other lecturers in the department. Two of the younger ones tried. The older ones said, "It's interesting, but I don't think I can teach like that." And they carried on delivering lectures basically. Their mode was lecturing, delivery, transmission of knowledge but fortunately Kobe University is fairly flexible, so I was allowed to teach in my way and they taught in their way. And the students chose.

VN: That's another issue, whether the principal, the administration or the syllabus will allow you.

BT: Well, that was the problem initially in Indonesia where we had a huge experiment, the PKG Project. One class in each secondary school, first year beginners of English, followed our approach, which was very much a humanistic approach. It was very different. And at first principals were worried; parents were worried. We got a lot of opposition; inspectors were worried. So, I involved them. I invited principals and inspectors to the workshops, and they sat in and they did the activities and they began to see that what we were doing was principled; it wasn't just at random; it wasn't ad hoc; it was very principled and very systematic, but it was humanistic at the same time. And then they worried the students would suffer in their exams, which everybody worries about because it's a standardised exam; they take it at the end of the year, but what actually happened was the students in our classes did much better than the others right across the country.

VN: ... because you taught them the way humans should be taught.

BT: Yes exactly. They were engaged, they were involved, they were exposed to more English and they had more confidence as human beings not just as students in the language classroom. They performed better even though we hadn't prepared them for their exam. And I've found that's happened in a number of countries.

VN: My next question is related to the past of humanising education. By past I mean the ancient Greece, ancient scholars, or the past centuries, but you choose which past to talk about. But to me ancient Greece had interesting models; for example, they didn't allow their students to talk. In fact, there was a long silent period of four years. Students were not allowed to ask questions. They just listened for four years before they started questioning which seems interesting to me. Allowing a silent period in language education is interesting. What's your view on that? Don't you think we have become dehumanised, as we have become more civilised?

BT: Yes, because there's more need to exert control; as the community gets bigger, there is a greater need to control. Yes, it's really interesting the model you just mentioned, because allowing silence is humanistic. Compelling silence isn't. And, it is in a way, reflecting the natural way of learning. We don't do things before we are ready. We create readiness and one way of doing that is to listen. But at the same time if you are compelling people to be silent who have become ready and curious, it's no longer humanistic. So again, it goes back to giving choice, being open, allowing space, allowing choices. I'm just thinking of the traditions in Africa, for example, where informal education is mainly as far as I know from storytelling. And I'm not sure but I suspect that even when it was an adult telling it to the children, that the children often would interrupt because certainly if you go to the theater in Africa, for example in Nigeria, the audience are not silent; they interact with the actors.

VN: And what kind of theater would that be?

BT: It's wonderful. In fact, the Nottingham Playhouse Company, every year (I don't know whether they still do it, but they used to); they used to go to Nigeria, and they would stage Shakespeare in a football stadium with 20,000 to 30,000 people. And the whole crowd would recite Hamlet's soliloquy. They knew the play, and they would shout out and interrupt and the actors loved it and they said this is how Shakespeare used to be. Shakespeare's audiences weren't silent; they shouted; they interacted; they were part of the drama. So, I don't know but I'm wondering if that also happened in the storytelling tradition. There is a form of reading now. It is known as the 'Big Book', the 'Shared Reader', where the learners sit around a large book, and the teacher reads it but every so often learners interrupt to ask questions, to make a point, make a comment, kind of noisy reading, but it's humanistic. Because you're sort of leading and directing but leaving an open space for intervention. Just like the way I do my plenaries where I invite people to interrupt at any time. 
VN: What you're saying is that education is becoming far from humanistic as we go on. Or is it not the case?

BT: You get trends; I mean in England things did change for a while, but it's been always associated with the political parties. So under the Labour Government, at one period, education did become more humanistic and assessment changed; a lot of continuous assessment was introduced. But, now under the Conservative Party, it's going back to a very, very rigid system of constant testing; you know, five-year-olds being tested. And now, they are introducing a test when the kids arrive in the primary school straight away. So, it's Test! Test! Test! And going back to what they call proper education, teaching long division, teaching the tables in mathematics, teaching grammar in English, and it's getting more and more restrictive, less and less open.

VN: You're saying it's not a matter of cross sections of humanising or dehumanising education, it could be a changing trend.

BT: It could be. And there have always been experimental schools outside the mainstream system; for example, the Montessori schools. In England, there have been a number of famous experiments with open education where the students write the rules and the students control themselves. And most of those experiments as far as I know have been fairly successful. But, it depends very much on the driving force of one person or maybe two people, and when they die or move on the experiment is often aborted.

VN: What I had in mind was asking you questions about the past, the present and the future of humanising education, but the way you answered me, I have begun to think this way that the matter of humanising or dehumanising education is not a matter of time. You could talk about the Greeks, for example; if you were a Greek master and you compelled your students to be silent, you were definitely not being humanistic. But, if you lived in the same period and allowed silence then you would be humanistic; then, perhaps it's not a matter of time, and it may not be possible to draw a map and indicate in which particular periods education has been more or less humanistic.

BT: That's right. Because it is easy to generalise about the past and we make generalisations based on surviving literature basically. But, it's less easy to generalise about the present talking about the education system. But, if you go to individual classrooms, you will find tremendous variation in how teachers are interpreting that system. Some teachers are much more humanistic than others within any system. In the end, it depends on the teacher. And the teacher's relationship with the learners. I worked at a college in England, called Bell College. It was quite a famous college in Essex.. And there were four of us called Brian. And we were known as the 'Four Brians', just like the 'Four Musketeers'. And I think we were all successful because we were all humanistic. But our methodology was completely different. One of them, his methodology was very traditional, grammar-based and transmission-of-knowledge-based. But he was a very interesting person, very interesting personality, and he had a very good relationship with the students, and they respected him. And they enjoyed his classes despite the methodology. And he was very successful. I was the opposite, I was doing projects, using literature, and getting them to dramatise poems, make videos of poems, etc. So we were completely different, but we got the same results and it was nothing to do with the methodology; it was to do with the personality and the relationship with the person. One of the other Brians was an artists, he used art a lot. And the other Brian was very interested in music, and he used music a lot. All four of us had different personalities, but we used our personalities and we respected the learners and we gave choice to the learners.

VN: So the key principles are emerging, giving choices and respecting individual learners.

BT: Yes, that's it. And it's not part of teacher training; you go to teacher training courses, you're taught the grammar of English. They dehumanise you. You enter as a human being and you come out as a teacher. And what I do in my teacher training is lifting the confidence of the person who is going to become a teacher so that they become a confident teacher and a relaxed, comfortable teacher, and they will enjoy teaching and then if they enjoy teaching, then they will help their students to enjoy it.

If teachers don't enjoy it, that's when they also start dehumanising because they must be in control and lessons must be easy to prepare. It's easy to prepare a dehumanised lesson because there are models to follow.

And if you are going to be humanistic, you don't have a script; you have a plan which is open-ended and can go in different directions. And you've got to be prepared. I used to take two lessons into the classroom with me, and when one wasn't going well, I'd switch to the other one.

VN: The next and perhaps the last question is related to the future. The future is becoming more and more technologybased. In fact, I was observing this group of students in an institute; they went through different classes, vocabulary, reading, grammar, and then writing, and well honestly I couldn't keep my eyes open in the writing class; it was an editing class. They didn't do any writing. So, at the end of the day, I asked the students what their favorite part was, and unanimously they said the language lab, which to me was supposed to be the most dehumanised part of language education experienced by those students that day because there was no human element as far I could see. What's your view on that? Do you think education will become more or less humanistic in the presence of technology?

BT: No, there is a great danger of it becoming less humanistic unless people follow the advice of going for blended learning, where you are doing with the technology what it is suitable for and doing with human face-to-face 
interaction what that is suitable for, combining the two. The technology can deliver the knowledge. The human being is necessary to stimulate, to engage, to involve, to facilitate, to be there as a resource. Combine the two, and there you go, humanistic education.

The dangerous word is 'interactive'. Most digital learning programmes claim to be interactive, but they are not interactive; all it means is if you get it right, there is a little song, but if you get it wrong, it chops your head off or something. That's not interaction, certainly, not humanistic interaction. It's not helping you to develop in any way. So, I'd ban the word interactive from the literature on technology; it's misleading. Technology can be interactive though; I'll give you an example. In Turkey, there is a course for taxi drivers. They often have to take overseas visitors to and from the airport and the language of communication is usually English. So they are doing a course, but because they are busy as taxi drivers, they don't often meet together in the classroom. So what happens is they do meet in the classroom maybe once a week. But then, they use their mobiles if they are waiting for a passenger in their taxi. So, while they are waiting for their passengers and have got nothing to do, they take out their mobile and they can download a lesson relating to interaction with a passenger. And then when they pick up a passenger, they put what they have just learned immediately into action, and ideally they record the conversation with the passenger with the passenger's permission. And then it can be sent to the teacher who can monitor it and give feedback. So that's a really good combination.

VN: Makes sense. Otherwise, how could it be interactive, if it doesn't have any online sort of support, with another human being on the other side?

BT: I jointly edited a book on blended learning, and for nearly every article, I wrote back saying, 'Where is the human interaction?' It hadn't been emphasised, they were emphasizing the technology; human interaction was actually there, but it wasn't being emphasised or highlighted. Then authors revised and improved their articles. So this is possible. In Singapore, there was a research study on creativity and they were trying to find out whether computers helped learners to become more creative or not. What I found was, yes, they do if students share a computer; no they don't, if students have one computer per student because if students start sharing a computer, they are talking all the time, they are helping each other. When they can't understand what to do, they work it out together and it's that, 'human interaction' where they actually apply language which counts, not so much the activity on the screen.

VN: So, I think another key word has emerged, 'interaction'.

BT: Yes.

VN: Our technology is going to help us remain or be more humanistic in our education if the human interaction element is there.

BT: That's right. It shouldn't just be a question of doing exercises and activities with no connection to the learner's real life and no interaction with other human beings.

VN: Sounds audio-lingual.

BT: A lot of it is. I was asked by Microsoft to review all the existing language learning programmes, this was quite a long time ago, because they were interested in developing programmes themselves; I don't know if they have done it. They brought me a beautiful computer, and all the software and I reviewed and evaluated the existing programmes. There were one or two good ones which were much more genuinely interactive, but most of them were just doing what any textbook would do whilst claiming all sorts of advantages. But, I've also found as I travel around the world that in many places they just don't have electricity. When I worked in Indonesia, schools sometimes had language laboratories donated by foreign aid, but no electricity; or they had nobody to maintain the lab, there were no spare parts and often no software, so they turned the lab into a meeting room for VIP visitors. So when I visited schools, my meeting with the Principal was often in the language lab because there was airconditioning.

But having said that, I was the Director of Studies at a college, where we had the first computer lab possibly in England. But what we did was, this was way back, we bought PCs, the Sinclair Spectrum, which was the first PC. So we bought twelve I think and put them in a room and then we said to ourselves, 'What do we want to do with them?' and 'What do we want these to do?' We had no idea what they could do, and then brought the technician in and said, 'What we want this computer to do is this... Can it do it?' He said, 'I'm not sure. Let's have a look.' So, instead of being driven by the computer, we were driven by pedagogical principles which we tried to then get the computer to help us to apply. So, we used it for things like Creative writing, where two students sat at a computer and they started a story, and then they moved on to the next computer. And what they did was that they would look at the story there and improve it and continue it. And people just moved around. And they talked and moved around. You can't really do that with pen and paper because it gets very messy. So we were taking advantage of the word processing system. That's the way it should be when people sit down to develop digital courses. What can we do with this technology which could be difficult to do without it?

VN: Any last words for teachers who want to be humanistic? 
BT: Yes, there is hope. I'm always optimistic. I've found that teachers do want to be humanistic, but they are scared of it. And they can do it with sufficient encouragement. Yesterday I had a workshop and teachers came up to me afterwards and said, "I'd really love to do that, but I don't think I can. And I told them, basically the first rule is, you've got to convince yourself that you want to do it and you can do it. After that, you might have to convince your colleagues; you've also got to convince you students. That's not difficult. When the students see it's more enjoyable, more engaging, well connected to their lives, they will prefer it. And they will be cooperative. So, all over the world where I have done teacher training, I have seen all of the teachers have seen the benefit for themselves, going away and doing it. The only problem is the teacher needs continued support and stimulus. I remember a group of teachers from Finland. They came for a course in England and they became more confident, more humanistic, and then they went back to Finland and made changes in what they were doing. And three years later, I went to a conference and they took me for dinner and they said, "We feel so guilty that we have come back to what we did before," but now you've come, we're stimulated again.

VN: There has to be some continuous stimulus.

BT: There has to be support from the system, so basically the inspectors have got to be humanistic in order for the teachers to be humanistic, and it can work. In Belgium, for example, we used to run courses for Belgian teachers. And the inspectors used to come with them but didn't sit in, and all the time the teachers were saying, 'This is great but the inspectors won't let us do that.' So, I invited the inspectors to sit in and I said, "Is that ok?", "Can the students do that?" And they said. "Yes, they can." and they became part of the team instead of being separate, and the inspectors stopped policing the teachers and started supporting them. And I think that's the main hope. The problem is the inspectors and ministry officials tend to be rather senior in age and in authority. And their natural instinct is to behave in an authoritative way. And they don't feel relaxed. I did this in Japan with an audience of eight hundred in a theatre, I did one of my Total Physical Response (TPR) drama ones where I got them all to act. I told a story and they acted it out and all 800 came on the stage. One of them was the senior educational officer for the area. So, I deliberately invited him. And he was doing it. And then when teachers asked, 'Can we do this in the schools?' I said, 'Here is a senior educational officer.' But, of course somebody said, 'Can you do that with large classes?' And I said, 'How many people are we? We're 800; that's a large class.' So I don't know what impact it had. Here, I'm obviously talking as if I'm the only person doing it, but there are many people out there doing it. I mean there is a journal called Humanising Language Teaching, a web journal. A lot of people read that and contribute to it. So, it's happening in little pockets around the world. And it's beginning to happen in foreign language teaching. Recently I have been to a number of conferences for teachers of French, Spanish, and Italian in universities in England. And I find in many ways they are much more humanistic. For many years they just resisted, stayed completely separate from TEFL. But now there is a lot of young energy, so ideas are coming from there. And that's very new. A lot of young energetic people coming up with new ideas. I went to a conference recently for an association called 'Flame'. They are interested in the use of video in education and in language education in particular. And I did a plenary at their conference and they were all teachers of foreign languages, using film and video, and they were very creative and a very interesting group of people. And they did have the confidence. So they were telling me they had applied some of the things that I was talking about and they were telling me what they were doing, and they were confident and creative teachers.

So there's hope.

VN: Thank you very much.

\section{Some Suggested Readings}

Humanising Language Teaching. www.hltmag.co.uk/index.htm

Rinvolucri, M. (2002). Humanising your coursebook. English Language Teaching Professional.

Tomlinson, B. (2008). Humanising an EAP coursebook. Humanising Language Teaching. www.hltmag.co.uk/index.htm

Tomlinson, B. (2013). Humanising the coursebook. In B. Tomlinson (Ed.) Developing materials for language teaching (pp. 139-156). London: Bloomsbury.

Tomlinson, B. (2015). Challenging teachers to use their coursebook creatively. In A. Maley \& N. Peachey (Eds.), Creativity in the Language Classroom. London: British Council.

Tomlinson, B. (forthcoming 2017). Making typical coursebook activities more beneficial for the learner. In D. Bao (Ed.), Creative concerns in ELT materials development: Looking beyond the current design. Bristol: Multilingual Matters. 